\title{
Benchmark for Partnership in Human and Material Resources Provision for Adult Education Programmes in the South-East Zone of Nigeria
}

\author{
Linus O. Nwabuko ${ }^{1}$, Ngozi J. Igwe ${ }^{1}$, Mary C. Okengwu ${ }^{1}$, Michelle A. Nwabuko ${ }^{1} \&$ Onyinye Ekere ${ }^{1}$ \\ ${ }^{1}$ Department of Adult Education and Extra-Mural Studies, University of Nigeria, Nsukka, Nigeria \\ Correspondence: Ngozi J. Igwe, Department of Adult Education and Extra-Mural Studies, University of Nigeria, \\ Nsukka. E-mail: ngozi.justina.igwe@unn.edu.ng
}

Received: December 11, 2019 Accepted: March 13, 2020 Online Published: March 22, 2020

doi:10.5539/gjhs.v12n5p46 URL: https://doi.org/10.5539/gjhs.v12n5p46

\begin{abstract}
Partnership is an approach used for effective human and material resources provision among agencies and partners based on democratic principles of understanding in pursuit of a common goal. Adult education programmes are provided by the government, Non-governmental Organisations (NGOs) and donor agencies. Yet adult education seems to suffer from a dearth of human and material resources due to a loose partnership framework among government NGOs and donor agencies. Hence the need to provide a benchmark for partnership among government, NGOs and donor agencies in the provision of human and material resources. Adopting a descriptive survey research design, the instrument was administered to 3202 subjects consisting of sixty-two proprietors of NGOs adult education centres, five directors of state agencies of mass literacy adult and Non-formal education, fifteen coordinators of donor agencies and 3120 adult education instructors. The data was presented using frequencies, percentages, means, standard derivations and analysis of variance (ANOVA). The study revealed that NGOs have to submit quarterly the record of their staff strength to state agencies for mass literacy adult and non-formal education for resource planning and that development of materials in multi-language can be achieved through collaborated efforts of stakeholders. Thus, the study recommended, among others, that state agencies for mass literacy, adult and non-formal education, NGOs and donor agencies should cooperate to organize conferences for capacity development and instructors and development material in multi-language for adult learners.
\end{abstract}

Keywords: adult education, benchmark, partnership, administration, human resources, material resources game theory.

\section{Introduction}

Adult education deals with everyday life activities of adults which include literacy programmes, remedial education, skill training programme and retraining programmes properly planned and implemented to improve the beneficiaries. It involves any kind of education designed for the illiterate population, the formal school dropout, the unskilled and semi-skilled workers, carried out outside the formal school setting (Eyibe, 2005). According to the Federal Republic of Nigeria (2013), the objectives of Adult and Non-formal Education were stated as;

(a) Provide functional basic education for adults and youths who have never had the advantage of formal education or who left school too early. The target groups include migrant folks, Almajiri pupils, illiterate and semi-literate adults, youths and adolescents, persons who left the formal school system early and now are willing to come back and continue schooling, and other categories of disadvantaged groups, who are unable to have access to the conventional education system and therefore require other forms of educational programmes to cater for their particular/peculiar needs and circumstances.

(b) Provide remedial and life-long education for youths and adult who did not complete secondary education; and

(c) Provide in-service, vocational and professional training for different categories of worker and professionals to improve their skills.

In Nigeria, there appears to be a general lack of commitment and strong political will by the government to pursue these laudable objectives of adult and non-formal education. Consequently, it seems the government has not shown major concern to adult education programmes but instead they formulate policies for the non-governmental 
organizations to implement. Agi (2008) emphasized a point made at a World Bank Education meeting in Paris which stated that desired results in adult education require bold policy reforms and sustainable implementation by partnerships of government, NGOs and donor agencies.

Partnership, according to Agi (2008), is the free association among agencies and partners based on democratic principles of understanding in the pursuit of business affairs and sharing the profit and losses. It allows partners to put together their strengths, recognize and rise above their weaknesses in their efforts at achieving a commonly agreed objective. Partnership in the administration of adult education programmes will make the governments, NGOs and donor agencies bring together their resources both human and material in achieving the goals of adult education. However, this partnership has not been successful in Nigeria largely due to the absence of benchmark for the effective administration of adult education programmes.

Adult and non-formal education is a sector that needs inter-sector collaboration, cooperation and coordination. In recognition of this, NMEC (2017:61) provided the partnership framework which mandates the commission on behalf of the federal government to organize at least biannual stakeholders meeting; seek for the support of the international development partner for the state; work in co-operation with other similar establishments like UBEC, NAPEP, NDA and relevant ministries; collaborate with national and international NGOs; link up with relevant Colleges of Education and Universities for training.

The above partnership expects states to collaborate with international development partners at zonal and state levels; hold meetings with them for collaboration, cooperation and coordination; collaborate with State Universal Basic Education Board (SUBEB), quranic school operators, etc on the integration of Quranic Education (QE) into Basic Education and solicit for community support or active involvement. Adult Education officers at the local government level were also authorized to meet with all local NGOs and stakeholders for consultation and collaboration; link up with relevant individuals and institutions on the training of facilitators; hold meetings regularly with the facilitators for programme success; community opinion leaders, local philanthropists etc for the purpose of cooperation and coordination; institute awards to promote more partnership.

The above partnership framework places more emphasis on an intra-governmental relationship but most adult education centres are established and operated by non-governmental organizations. The donor agencies also fund most adult education programmes in the South East (Obasi, 2004). Nwabuko, (2004) observed that there is no strong partnership existing among government, NGOs and the international donor agencies in the administration of adult education programmes rather, a weak representation which does not afford them full participation as partners. This is in contrary to what was stipulated in the National Policy on Education (NPE, 2013). According to the document, partners should involve and engage actively in the activities and programmes commonly agreed upon through joint mobilization of human and material resources for the effective administration of adult education in Nigeria.

In addition to the problem of unequal and weak partnership, adult education also suffers from undue financial neglect and constraints (Akinkpelu, 1992; Nwabuko, 2004). In order to adequately respond to this neglect, developing a benchmark for partnership is a sine-qua-non for adequate human and material resources provision in the administration of adult education programmes.

Benchmarking is an ongoing systematic process for measuring and comparing the work processes of one organization with those of another for the purpose of identifying best practices that can lead to an improvement in operation and customer service (Shafer \& Coate, 1992). It provides direction and clear targets, and allows partners to answer two questions: what are we doing well now, compared to others like us, and what do we need to do better if we are to improve our performance? The objective of benchmarking is to assist a programme to establish baseline performance criteria for the partners to abide. Hence appropriate partnership benchmarks in human and material resources in the administration of adult education programmes can help to avoid duplication in programmes and services provided by the partners, and establish commitment measures for the administration of adult education programmes.

Adult education administration function entails continuous decision-making that affects the use of both human and material resources to produce the desired result. In corroboration with this view, Barikor (1991) identified the major factors in the effective administration of adult education to include management of human resources and adequate provision of material resources. Realization of adult education programme objectives, therefore cannot take place without effective human and material resources for the effective administration of adult education programmes.

Human resources management (HRM) as defined by Ikeanyibe (2009) is a set of organizational activities directed 
to attracting, developing and maintaining an effective workforce. Human resource management encompasses those activities designed to provide for and coordinate the human resources of an organization (Byars \& Lesile, 2004). Organizational success depends largely on people. Thus, an organization must of necessity attract the right kind of human beings, retain and maintain them in the right frame of mind to give their best efforts towards achieving the organization goals.

Human resources in education according to Iyede (1995) is not only effective utilization of people at work but the harnessing of the totality of the people's skills, energies, talents, latent capacities, social characteristics, like belief, to achieve educational objectives and simultaneous making the people to be part and parcel of organization in fulfilling their life goals. It is the systematic utilization of human potentials to realize educational objectives and staff contentment.

The attainment of an educational objective is very much linked with the availability of human resources and their management. This is because no matter how well a curriculum has been planned, the teacher, in the final analysis, determines what is actually taught and how well it is taught. The organizational patterns for instruction must be planned along with the development of the total programme. According to Nwabuko, a successful curriculum and a dynamic administration go hand in hand and one cannot operate at maximum efficiency without the other. Coordination of planned programme, maximum utilization of the multiple talents of educators and optimum exposure between educators and learners are all necessary functions of administration. It is the administrators' special task to provide the wherewithal and atmosphere necessary to facilitate the work of the educator. Human resource management is therefore, considered a very important resource in education.

In adult education, the deplorable condition of the human resources is alarming. Most workers in adult education agencies are not trained adult educators. The formal school teachers and secondary school dropouts dominate the entire system (Odiuaran, 1991). Oduaran (1991) observed that hundreds of thousands of those managing voluntary adult associations, adult training programmes, seminars, symposia, and conferences for adult and continuing education programmes among a host of others claim to be adult educators. This situation is unhealthy to the field of adult education. Few of them are aware that there is a growing body of knowledge and techniques that they can learn to help them perform this role better (Oduaran, 1991). Furthermore, Akintayo (1998) observed that all the seven Directors of the South-West and the five Directors of the South-East zones of the agencies of mass literacy, adult and non-formal education in Nigeria, are not trained adult educators but bureaucrats who are just selected or picked from various ministries.

Adult education cannot make do with this kind of personnel because rigorous training programmes for professionals in the area are common now. Presently, adult educators can be categorized according to the levels at which they serve. Oduaran (1990) prescribe this categorization in three levels as the firing-line the programme-director level and the professional-leadership level. According to him, the beauty in this categorization is that it tries to identify adult educators using the equivalent of their functions or roles in the service. Those at the firing-line level are grassroots workers, educators, those who are diagnosing adult learning needs, those working to plan the adult learners learning experiences, those providing the resources to facilitate learning and those trying to find out whether learning has taken place. At this level, the programme director level encompasses those performing diagnostic, organizational, planning, administrative and training as well as evaluating functions (Oduaran, 1991). The professional leadership level are a crop of adult educators who strive relentlessly to develop new knowledge, preparing curricula materials, introducing modern techniques of doing the job, training adult educators, coordinating the activities of agencies with interest in adult education, contributing ideas that should guide policy formulations and leading researches among a host of other functions (Oduran, 1991).

Commenting on unqualified personnel, Akintayo (1998:48) observed that:

At the central level or high levels, frequent staff turnover and expansion are common, contributing to unstable policies and practices. Key positions may be filled by individuals who have little experience in adult education policy and planning, often because they have been rapidly promoted or appointed to fill vacancies.

In a similar remark, Akintayo also observed that institutes that train adult educators are limited in number and often handicapped by the shortages of staff, teaching materials and in many cases, funds. Nevertheless, rather than labour themselves to address the issue of the background of adult educators, professionally trained adult educators are now preoccupied with the training of new and existing personnel in the field. This task of training of instructor is by no means simple. Its complex nature requires the contribution of governments, NGOs and donor agencies in the field of adult education. 
The dearth of necessary materials such as primers, class readers, designed to suit the needs of adult learners, is a major problem hindering effective administration of adult education programmes in Nigeria. In many cases, adult education instructors make use of materials which have been designed for children in primary schools and in such cases, these materials do not meet the needs and interests of adult learners. Before the learner, the learner and the society achieve their common objectives in education, there must be some material resources in use (Nwabuko, 2014). Material resources consist of the building, capital equipment, non-capital equipment, audiovisual soft-ware, books and stationeries.

Explaining issues in the area of material resources for adult education, Toby (1991) observes that equipment in adult education is in the domain of those instructional items or devices which fall into the category of hardware that is the in-expendable instructional items whereas materials which fall under the expendable instructional items are classified as software.

The most important factor in this discussion is the provision or mobilization of these instructional items than to what use in which they are put. In all countries in Africa, existing resources are inadequate to achieve quality basic non-formal education or quality adult education (Okediran, 1998). As a result, stakeholders must take steps to mobilize additional resources for adult education.

The purposes of the study, therefore, is to develop a benchmark for effective partnership in human and material resources provision for adult education programmes in the South East, Nigeria. Specifically, the study sought to;

(1) Ascending ways of establishing a partnership in human resource development and management among government Non-government Organisation (NGOs) and donor agencies in the administration of adult education programmes.

(2) Find out strategies for establishing partnership among government, NGOs and donor agencies in the provision of materials for the administration of adult education programmes.

Following from the specific purposes, two research questions guided the study;

(1) In what ways could partnership be established among government, NGOs and donor agencies to ensure human resources development and management in the administration of adult education programmes?

(2) What strategies could be evolved in establishing partnership among government, NGOs and donor agencies in the provision of material resources in the administration of adult education programmes?

\subsection{Hypotheses}

$\mathbf{H O}_{1}$ : There are no significant differences among the mean ratings of the state agency for mass literacy, adult and non-formal education officials, proprietors of adult education centres, coordinators of donor agencies and instructors, on ways of establishing a partnership in human resources development and management of adult education-programmes.

$\mathbf{H O}_{2}$ : There are no significant differences among the mean ratings of the state agency for mass literacy, adult and non-formal education officials, proprietors of adult education centres, state coordinators of donor agencies and instructors on ways of establishing a partnership in the provision of material resources for adult education programmes.

\section{Research Procedure}

The study used a descriptive survey research design. Descriptive survey research according to (Nwaogu, 2015), tries to unravel the major elements and characteristics of any phenomenon or attitude. The descriptive design also focuses on people and their beliefs, opinions, attitudes, motivations and behaviour,(Obetta \& Oreh, 2017). The study covered the five states in the South-East geopolitical zone of Nigeria namely; Abia, Anambra, Ebonyi, Enugu and Imo. The choice of this zone was motivated by the fact that this area is well known for their efforts in acquiring education. But the absence of benchmark as a measure for effective partnership in the administration of adult education in the zone seems to limit their effective participation in adult education programmes.

The population of the study was 3202 subjects. It included all the sixty-two(62) proprietors of NGO's operating Adult Education Centres, all the five (5) State Directors of Agencies of Mass Literacy, Adult and Non-formal Education, all the fifteen (15) Coordinators/State Programme Monitoring Advisers (SPMA's) in all the UNDP, UNICEF and UNESCO offices and all the three thousand, one hundred and twenty $(3,120)$ adult education instructors in the five states (Abia, Anambra, Ebonyi, Enugu and Imo). (source, NMEC Zonal Office, 2009).

The sample of the study was 394 subjects. In constituting the sample, all the 62 proprietors of NGOs operating Adult and Non-formal Education in the five states, 15 coordinators of UNDP, UNICEF, and UNESCO, were all 
used due to the manageable size of their population. Purposive sampling technique was used to select 48, 56, 74, 68 and 66 instructors from Abia, Anambra, Ebonyi, Enugu and Imo States respectively. These are the number of instructors selected to attend instructor's conference from each of the states.

The instrument was a structured questionnaire developed by the researcher titled "Questionnaire for Benchmark in human and material resources partnership in the Administration of Adult Education Programmes" which was used to collect the required information from the respondents.

To determine if the instrument was capable of measuring what it was designed to measure the questionnaire was face and content validated by two lecturers in the Department of Adult Education and two lecturers in the Department of Science Education of the University of Nigeria, Nsukka. They went through the instrument and made their criticisms and comments.

The reliability of the instrument was tested using thirty-seven (37) respondents consisting seventeen (17) proprietors, one director, three co-ordinator and 12 proprietors, one director and three coordinators from Cross-River and Akwa-Ibom States respectively. The Cronbach alpha method was used to estimate the reliability index because the items in the instrument were not dichotomously scored. The consistency for each of the subsections of the instrument was established and the results yielded. 72, 91, 80 and 90 for each of the clusters. The overall value of 0.91 was obtained permitting the conclusion that the instrument was reliable.

The data generated were statistically analyzed using mean scores and analysis of variance (ANOVA). Means score was used to answer research questions 1-2 while ANOVA was used to test hypotheses 1-2. This is because the statistics involved item analysis.

\section{Results}

\subsection{Research Questions 1}

In what ways could the government, NGOs and donor agencies cooperate to ensure effective human resource development and management of adult education programmes in the South East Zone of Nigeria?

Table 1. Mean Rating of Benchmark for Partnership among Government, NGOs, Donor Agencies on Human Resource Development and Management

\begin{tabular}{|c|c|c|c|c|c|}
\hline $\mathbf{S} / \mathbf{N}$ & Item & $\begin{array}{l}\text { Mean } \\
\text { value }\end{array}$ & $\begin{array}{l}\text { SD } \\
\text { value }\end{array}$ & Rank & Remark \\
\hline 1 & $\begin{array}{l}\text { Non-governmental organization adult education centres } \\
\text { should submit quarterly the records of staff strength of their } \\
\text { concerns of NMEC for planning purposes. }\end{array}$ & 3.60 & .78 & $1^{\text {st }}$ & Agree \\
\hline 2 & $\begin{array}{l}\text { Trained adult educators should be freely exchanged by } \\
\text { government, NGOs and donor agencies. }\end{array}$ & 3.21 & .80 & $7^{\text {th }}$ & Agree \\
\hline 3 & $\begin{array}{l}\text { Conference programmes and adult education administration } \\
\text { can be organized regularly by government, NGOs and } \\
\text { donor agencies for the benefit of all. }\end{array}$ & 3.41 & .77 & $2^{\text {nd }}$ & Agree \\
\hline 4 & $\begin{array}{l}\text { Adult instructors should be posted as resource persons to } \\
\text { both government and NGOs centres according to need. }\end{array}$ & 3.17 & 82 & $8^{\text {th }}$ & Agree \\
\hline 5 & $\begin{array}{l}\text { Government should willingly post adult instructors from } \\
\text { National Youth Service Corps (NYSC) to NGO's adult } \\
\text { education centres in areas of need. }\end{array}$ & 3.35 & .80 & $3^{\text {rd }}$ & Agree \\
\hline 6 & $\begin{array}{l}\text { A common award scheme should be provided for instructors } \\
\text { of outstanding qualities in adult education centres. }\end{array}$ & 3.28 & .92 & $.5^{\text {th }}$ & Agree \\
\hline 7 & $\begin{array}{l}\text { Adult education instructors should receive some pay as } \\
\text { primary school teachers. }\end{array}$ & 3.27 & 3.27 & $5^{\text {th }}$ & Agree \\
\hline 8 & $\begin{array}{l}\text { NMEC officials should be represented in disciplinary } \\
\text { panels for instructors in NGOs adult education centres. }\end{array}$ & 2.90 & .92 & $10^{\text {th }}$ & Agree \\
\hline 9 & $\begin{array}{l}\text { A special provision of in-service training of NGOs adult } \\
\text { education instructor should be made by the government }\end{array}$ & 3.28 & .89 & $4^{\text {th }}$ & Agree \\
\hline
\end{tabular}




\begin{tabular}{llllll}
\hline 10 & $\begin{array}{l}\text { Welfare scheme committee set up by the government should } \\
\text { include instructors from NGOs adult education centres. }\end{array}$ & 3.12 & .84 & $9^{\text {th }}$ & Agree \\
\hline 11 & $\begin{array}{l}\text { Condition of service of NGOs instructors should be } \\
\text { submitted regularly to NMEC for evaluation }\end{array}$ & 3.22 & .93 & $6^{\text {th }}$ & Agree \\
\hline Grand means & $\mathbf{3 . 3 0}$ & Agree \\
\hline
\end{tabular}

Table 1 shows that the mean ratings of respondents on benchmark for partnership among government, NGOs and donor agencies on human resource development and management range from 2.90 to 3.60. Item 1 was rated highest $\left(1^{\text {st }}\right)$ while item 8 was rated lowest $\left(10^{\text {th }}\right)$. However, all the items were rated above the cut-off point of 2.50 signifying that the respondents agree to the inclusion of all the items in the benchmark. The standard deviation of the items ranges from .77 to .92 explaining that the respondents were close in their ratings. The grand means of 3.30 shows that the respondents agree on the suggested areas of partnership among the stakeholders in human resource development and management.

To further analyze the different reactions among directors of agency for mass education, proprietors, coordinators instructors, hypothesis 1 was tested below.

HO$_{1}$ : There are no significant differences among the mean ratings of the state agency officials, proprietors of adult education centres, coordinators of donor agencies and instructors on ways of partnership in human resources development and management among the government, NGO and donor agencies.

In order to test the hypothesis 1, Analysis of Variance (ANOVA) of the difference among agency for mass literacy, adult and non-formal education officials, proprietors of NGOs adult education centres, coordinators of donor agencies and instructors of adult education centres were computed and the result is shown on Table 2 below:

Table 2.Analysis of variance (ANOVA) on Partnership for Human Resource Management and Development among Respondents

\begin{tabular}{llllll}
\hline Source & Sum of squares & Df & Mean & F & Significant of $\mathbf{p}$ \\
\hline \multirow{2}{*}{ Between Groups within Groups } & $\mathbf{3 . 1 7 6}$ & $\mathbf{3}$ & $\mathbf{1 . 0 5 9}$ & \multirow{2}{*}{$\mathbf{4 . 5 1}$} & $\mathbf{. 0 0 4}$ \\
& $\mathbf{9 1 . 3 7 5}$ & $\mathbf{3 9 0}$ & $\mathbf{. 2 3 4}$ & & \\
\hline Total & 94.551 & 3,93 & & & \\
\hline
\end{tabular}

Table 2 indicates that there are significant differences in the mean ratings of the state agency officials, proprietors of adult education centres, donor agencies staff and instructors. This is shown by the calculated F of 4.51 which is significant at .004 and also significant at .05 level. The null hypothesis is rejected.

\subsection{Research Questions 2}

What material resource strategies can be evolved by the government NGOs, and donor agencies in the administration of adult education programmes in the South-East zone of Nigeria. 
Table 3. Mean Rating of Partnership in Materials Resource Strategies among Government, NGOs and Donor Agencies

\begin{tabular}{|c|c|c|c|c|c|}
\hline $\mathbf{S} / \mathbf{N}$ & Item & $\begin{array}{l}\text { Mean } \\
\text { value }\end{array}$ & $\begin{array}{l}\text { SD } \\
\text { value }\end{array}$ & Rank & Remark \\
\hline 11 & $\begin{array}{l}\text { The government should provide free accommodation for } \\
\text { the adult education programme of NGOs }\end{array}$ & 3.32 & .83 & $2^{\text {nd }}$ & Agree \\
\hline 12 & $\begin{array}{l}\text { Sufficient books for adult learners eg primers should be } \\
\text { provided by the government, NGOs and donor agencies }\end{array}$ & 3.30 & .73 & $3^{\text {rd }}$ & Agree \\
\hline 13 & $\begin{array}{l}\text { Government, NGOs and donor agencies should ensure that } \\
\text { materials designed for children in primary schools should } \\
\text { not be used for adult education }\end{array}$ & 3.13 & .91 & $8^{\text {th }}$ & Agree \\
\hline 14 & $\begin{array}{l}\text { Government, Non-government organizations and donor } \\
\text { agencies should provide adequate media for instruction in } \\
\text { adult education }\end{array}$ & 3.24 & .82 & $5^{\text {th }}$ & Agree \\
\hline 15 & $\begin{array}{l}\text { Government, NGOs and donor agencies partnership in the } \\
\text { provision of material resources are not adequately utilized }\end{array}$ & 2.97 & 1.02 & $9^{\text {th }}$ & Agree \\
\hline 16 & $\begin{array}{l}\text { Development of materials in adult education in } \\
\text { Multi-languages can be achieved through collaborative } \\
\text { efforts of organizations. }\end{array}$ & 3.42 & .87 & $1^{\text {st }}$ & Agree \\
\hline 17 & $\begin{array}{l}\text { The material at the disposal of governments should be } \\
\text { complemented by NGOs materials for adult education } \\
\text { programmes }\end{array}$ & 3.13 & 1.89 & $7^{\text {th }}$ & Agree \\
\hline 18 & $\begin{array}{l}\text { NGOs should be involved in mobilizing materials for } \\
\text { effective implementation of adult education programmes }\end{array}$ & 3.15 & 1.89 & $7^{\text {th }}$ & Agree \\
\hline 19 & $\begin{array}{l}\text { Organizations in adult education should be involved in } \\
\text { recommending test books for adult education }\end{array}$ & 3.13 & .81 & $8^{\text {th }}$ & Agree \\
\hline 20 & $\begin{array}{l}\text { Government, NGOs and donor agencies should collaborate } \\
\text { in the provision of libraries to learners }\end{array}$ & 3.13 & .98 & $8^{\text {th }}$ & Agree \\
\hline 21 & $\begin{array}{l}\text { Materials at the disposal of governments should be } \\
\text { complement by donor agencies materials for adult } \\
\text { education programmes }\end{array}$ & 3.17 & .83 & $6^{\text {th }}$ & Agree \\
\hline 22 & $\begin{array}{l}\text { Donor agencies should be involved in mobilizing materials } \\
\text { for effective implementation of adult education } \\
\text { programmes. }\end{array}$ & 3.27 & .90 & $4^{\text {th }}$ & Agree \\
\hline & Grand means & 3.20 & & & Agree \\
\hline
\end{tabular}

Table 3 shows that the mean ratings of respondents on partnership in material resources strategies among government, NGOs and donor agencies range from 2.97 to 3.42 . Item 17 was rated highest $\left(1^{\text {st }}\right)$ while item 16 was rated lowest $\left(9^{\text {th }}\right)$. However, all the items were rated above the cut-off point of 2.50 signifying that the respondents agree to the inclusion of all the items in the benchmark. The standard deviation of the items ranges from .74 to 1.89 explaining that the respondents were close in their ratings. The grand mean of 3.20 shows that the respondents agreed on the suggested strategies of material resource provision among stakeholders.

HO2: There are no significant differences among the mean ratings of the state agency for mass education officials, proprietor of adult education centres, state coordinators of donor agencies and instructors on ways of partnership in material resources provision for adult education programmes in the South-East of Nigeria.

In order to tests Hypothesis 2, Analysis of Variance (ANOVA) of the difference among respondents was computed and the result is shown in Table 4 below: 
Table 4. ANOVA on Respondents Ratings on Ways of Partnership for Provision of Material Resources for Adult Education Programmes

\begin{tabular}{llllll}
\hline Source & Sum of squares & Df & Mean & F & Significant of p \\
\hline Between Groups & 4.65 & 3 & 1,0553 & 5.26 & .001 \\
Within Groups & 101.42 & 3.90 & .260 & 2.60 & \\
\hline Total & 106.083 & 3.93 & & & \\
\hline
\end{tabular}

Table 4 indicates that there are significant differences in the mean ratings of the state agency officials, proprietors of adult education centres, donor agencies staff and instructors. This is shown by the calculated F of 5.26 which is significant at .001 and also significant at .05 level. The null hypothesis is rejected.

\section{Findings}

1) It was the opinion of the respondents that NGOs adult education centres should submit quarterly the records of their staff strength to NMEC for planning purposes, conference programmes on adult education be organized regularly by government, NGOs and donor agencies; government should willingly post adult education instructors from National Youth Service Corps (NYSC ) to NGO adult education centres in areas of need, providing a common award scheme for instructors of outstanding qualities in adult education centres, a special provision of in-service training for NGOs adult education instructors by government, paying adult education instructors as the primary school teachers and submitting conditions of service of NGOs adult education instructors to NMEC for evaluation.

2) The finding further revealed that there were significant differences among the mean ratings of the state agency for mass education officials, proprietors, coordinators of donor agencies and instructors on ways of partnership for human resource development and management in adult education programmes. The hypothesis was therefore rejected at 05 levels of significance.

3) The respondents agreed that development of materials in adult education in multi-languages can be achieved through collaborative efforts of organizations providing free accommodation for adult education programmes of NGOs by the government; providing sufficient books for learners by government, NGOs and donor agencies; involving donor agencies in mobilizing materials for effective implementation of adult education programmes, providing adequate media for instruction in adult education by government, NGOs and donor agencies; complementing materials at the disposal of government by material from donor agencies; involving NGOs in mobilizing materials for effective implementation of adult education programmes; ensuring that materials designed for children in primary schools are not used for adult education.

4) There were significant differences among the mean ratings of the state agency for mass education officials, proprietors, coordinators of donor agencies and instructors on partnership for the provision of materials resources in adult education programmes. The hypothesis was therefore rejected at .05 level of significance.

\section{Discussion}

5.1 Ways of Partnership among Government, NGOs and Donor Agencies on Human Resource Development and Management in the Administration of Adult Education Programmes

The respondents (Table 1) agreed to all the items which include quarterly submission of records by NGOs to NMEC for planning scheme for the instructors and special provision of in-service training for instructors as ways of stakeholder's partnership on human resources development and management in administration of adult education programmes.

This is line with the stated responsibilities of the National Commission for Mass Literacy, Adult and Non-formalEducation (NMEC) whose responsibilities include among other things the coordination of all adult education activities undertaken by the NGOs within the state (NMEC, 2015). According to the National Blueprint for Adult and Non-formal Education (2015), the government should organize seminar, conferences and workshops for instructors for their training and development in adult education principles and practice.

Furthermore, the finding is in line with Hinzen M.R (2008) who observed that the success of any adult literacy programme depends on some checklists which include facilitators to be those who receive substantial initial training and regular refresher training, and the payment of facilitator/instructors the equivalent of the minimum wage of a primary school teacher. Consequently, Nwabuko (2014) found out that instructors of adult education programmes are not committed to their duties largely due to the fact they are poorly paid. According to the author, 
their salaries range from N350 to N500 per month which is not very rewarding and cannot motivate them to show commitment. Little wonder UNESCO (2016) reported that most instructors in adult computer literacy programmes are part-time workers. This goes to support the present study that there is a need for a partnership of stakeholders.

The finding that government should willingly post adult education instructors form NMEC to NGOs adult education centres in areas of need and provision of common award schemed for instructors of outstanding qualities in adult education centres, strengthens the thesis that state governments support is critical to the success of NGOs and donor agency's assistance in adult education.

The result of the analysis of the third null hypothesis indicated that there were significant differences in the mean ratings on ways of partnership for human resource development and management in adult education programmes. The observed difference may be attributed to the high self-ratings of the NGOs and instructors.

\subsection{Partnership in Material Resources Strategies among Government, NGOs and Donor Agencies}

It was the opinion of the respondents that stakeholders should collaborate in developing material and adult education in multi-language, the government should provide free accommodation for the adult education programme of NGOs; government, NGOs and donor agencies should provide books for learners; donor agencies should be involved in mobilizing materials for effective implementation of adult education programmes, adequate media for instruction in adult education should be provided by the government, NGOs and donor agencies, materials at the disposal of government should be complemented by materials from donor agencies and NGOs, ensuring that materials designed for children in primary schools are not used for adult education by government, NGOs and donor agencies and involving organizations in adult education in recommending textbooks for adult education.

This finding is in line with Oluborode (2007) who advocated that stakeholders who are interested in the administration of adult education programmes should jointly provide materials for the implementation of programmes. According to Obasi (2004), UNDP support and material resources are only complementary to national and state governments sources. This means that national and state governments should reciprocate the good gesture of the donor agencies by cooperating and making timely provision of adequate material resources to adult education programme implementation. UNESCO (2001) confirmed that Nigeria has an average literacy rate of $54.1 \%$, thereby placing Nigeria as one of the low literacy countries of the world with over 50 million illiterates. Therefore, lack of partnership among government, NGOs and donor agencies has resulted in inadequate provision of material resources as revealed by this study. This may have affected the high success that could have been recorded through adult education programmes. There is need for government to provide adequate material resources for NGOs adult education if they must strive and contribute their quota in the efforts in providing education for all.

To further explore information about government, NGOs and donor agencies partnership in the provision of materials resources, Table 9 reveals that a significant difference exists in the mean ratings of the respondents on partnership for the provision of material resources, Table 9 reveals that a significance exists in the mean ratings of the respondents on partnership for provision of material resources in adult education programme at 0.05 level of significance. The observed difference indication may be attributed to the obvious fact that while the agency for mass literacy officials (government) are shading off the responsibility for providing resource material for adult education centres, the donor agencies, on the other hand, made a serious case for government involvement, cooperation and collaboration in this regard.

Here lies the need for a benchmark for effective partnership among government donor agencies and NGOs in the administration of adult education programmes in the South East Zone of Nigeria.

\section{Conclusion}

Based on the findings of the study, the following conclusions were drawn.

The State Agency for Mass Literacy, Adult and Non-formal education officials, proprietors of adult education centres, coordinators of donor agencies and instructors agreed on the suggested ways in which government, NGOs and donor agencies can be involved in human resource management and development, in the administration of adult education programmes.

They agreed on all the forms of material resources provision partnership among stakeholders as suggested by the study.

\section{Recommendations}

1). The state agencies of Mass Educations NGOs and donor agencies should cooperate and organize regular 
conference programmes and adult education for their staff. This is necessary since conference programmes are good avenues for improving instructors for their job. NGOs centres should submit quarterly the records of their staff strength to NMEC for planning purposes. This will enable NMEC to involve their staff in general human resource development plans.

2). State agencies of Mass Education, NGOs and donor agencies should collaborate in developing material in multi-language in adult education and provide adequate books for learners. The government should provide free accommodation for adult education programmes of NGOs. These are necessary since NGOs cannot provide all the material resources needed in the various centres as most of the materials are specially made for adult teaching and learning.

3). The state agencies for Mass Education, NGOs and donor agencies. This is necessary since programme monitoring and supervision improve programme implementation; stimulate professional growth and development of instructors for enhanced performance in their jobs. State agencies for mass education should include the staff of NGOs and donor agencies as programmes supervisors; organize centrally the training programme of monitors and supervisors. This is necessary to engender the desired partnership among the stakeholders.

\section{Competing Interests Statement}

The authors declare that there are no competing or potential conflicts of interest.

\section{References}

Aderinoye, R. A. (1997).Literacy education in Nigeria. Ibadan: University Press.

Afrik, J. (1998). International input in adult education research in Africa. In M. Omolewa, E. E. Osuji, \& A. B. Oduaran (Eds.), Retrospect and renewal: The state of adult education research in Africa (pp. 12-22). Dakar Senegal: UNESCO.

Agi, U. K. (2008). Partnership approach to the management of universal basic education programme.Adult education in Nigeria. The Journal of the Nigerian National Council for Adult Education, Ibadan: NNCAE.

Akinkpelu, J. A. (1991). From pedagogy to Andragogy, identifying appropriate approaches to literacy teaching in Nigeria. Proceeding of the 19th National seminar functional literacy of the department of adult education, University of Ibadan.

Ali, A. (2006).Conducting research in education and the social sciences. Enugu: Tashiwa Networks Ltd.

Barikor, C. N. (1991). Administration of adult education programmes, In E.T. Ehiametalor\& A.B. Oduara (EDs), Fundamental of adult education (pp.139-146). Benin: NERA Publishers.

Byars, L. L. M. P. (2004). Human resource management(7th Ed). Boston: Hill Irwin.

Davis, M. D. (1970). Conventional application game theory in organizations partnership. Journal of Social Relative, 20, 9-17.

Day, R., \& Day, J. A. V. (1977). A review of the current state of negotiated order theory: An appreciation and a critique. Sociological Quarterly, 18(1), 126-142. https://doi.org/10.1111/j.1533-8525.1977.tb02165.x

Dye, T. R. (1975), Understanding public policy.Englewood Chiffs. New Jersey: Prentice Hall, Inc.

Eyibe, S. C. (2005). The nature and scope of adult and scope of adult education.In S.C. Eyibe (Ed.), Curriculum fundamentals of adult educational (pp 1-8). Onitsha: Innoson Publication Ltd.

Federal Republic of Nigeria. (2008).National blueprint for adult and non-formal education in Nigeria. Abuja: NMEC.

Federal Republic of Nigeria, (2015).National policy on education. Abuja Government Press

Gray, B. (1989). Collaborating: Finding common ground for multiparty. SanFrancisco CA: Josspy-Bass Publishers.

Gray, B., \& Wood, D. J. (1991). Collaborative alliances: Moving from practice to theory. Journal of Applied Behavioural Science, 27(1), 3022. https://doi.org/10.1177/0021886391271001

Ikeanyibe, O. M. (2009). Principles and practices of public personnel administration: a Nigerian perspective. Perfect Image.

Iyede, R. O. (1995): Managing human resources in education. In V.F. Peretomode (ed.),Introduction to educational administration, planning and supervision (pp. 72-81), Lagos: Joja Press Ltd. 
Lessen, C. (1979). Reaching the assetless rural poor. Development Digest, XVII. Washington, D.C. National Planning Association.

National Mass Education Commission. (2007). Annual report. Abuja:NMEC

National Commission for Mass Literacy Adult Non-Formal Education. (1998). Report of 1995-1997 terminal review on the FGN/UNDP. NIR/A3

National Mass Education Commission. (2008). National benchmark for non-formal education and integrating basic education into Quranic schools in Nigeria.

Nwabuko, L. O. (2013).Optimizing ICT in strategic planning and administration of adult education in Nigeria. Review of education. Journal of institute of education.24(1).

Nwabuko L. O. (2014). Benchmark for partnership in the administration of Adult Education: The Nigerian Perspectives. Enugu: Prince Digital press

Nwabuko, L. O., Nwaubani, O., \& Nwobi, A. U. (2016). Financial and decision making partnership in the administration of adult education in the South East Zone of Nigeria. Transyliruma Review, XXIV(II)

Obasi, S. N. (2004). The UNDP and community development projects in Nigeria. A comparative study of government contributions in the South-East geopolitical zone. Journal of Adult Education and Development (JAED), 2(1), Department of Adult Education and Extra-Mural Studies, UNN.

Obasi, S. N. (2006). Impact of United Nations Development Programme (UNDP) on sub-Saharan Africa: evidence from Nigeria and its implications for the millennium development goals. Adult education in Nigeria, 11 . Ibadan: NNCAE

Obetta, C. K., \& Oreh, C. I. (2017).Utilising planning and financing strategies in the management of Community Development Projects in Enugu State, Nigeria. Africa Education Review, 14(3-4), 52-66. https://doi.org/10.1080/18146627.2016.1224565

Okediran, A. (1998). Adult literacy education in the twenty-first century. In M. Omolewa\& E.E. Osuji (Eds.), Retrospect and renewal: the state of adult education research in Africa (pp. 205-214). Senegal: UNESCO.

Ologe, C. (1990). The role of government in the provision and promotion of adult literacy.Education Today, (1) 4-6

Shafter, B. S., \& Coate, L. E. (1992).Benchmarking in higher education. NACUBO Business Office, November 28-35

Sharma, M. P., Sadana, B. L., \& Herpreet, L. (2011). Public administration in theory and practice. Allahabad India kitabmahal printing.

Toby, U. T. (1991). Instrumental procedures, materials and equipment. In E. T. Ehiametalor, \& A. B. Oduran, (Eds.) Fundamentals of adult education. Benin City: NERA Publishers.

UNESCO. (1987).The definition and measurement of literacy. Journal of Adult and Youth Education, (1).

UNESCO. (1989). International literacy year.UNESCO document. June

UNESCO. (2016). Revitalizing adult and youth literacy (RAYL) in Nigeria 2012-2015 final report. Abuja: UNESCO.

\section{Copyrights}

Copyright for this article is retained by the author(s), with first publication rights granted to the journal.

This is an open-access article distributed under the terms and conditions of the Creative Commons Attribution license (http://creativecommons.org/licenses/by/4.0/). 